No. 185

July 2003

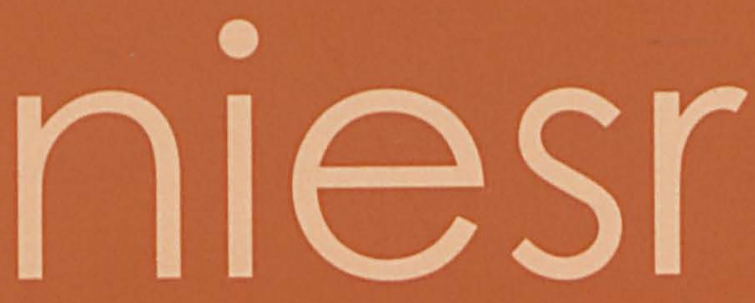

National Institute Economic Review 


\section{National Institute of Economic and Social Research}

\section{Discussion Papers}

No. 212.

Designing and choosing macroeconomic frameworks: the position of the UK after 4 years of the euro

by Ray Barrell and Martin Weale

Current fiscal and monetary frameworks in the UK and the Euro Area are evaluated, and suggestions made as to where they can be improved.

No. 213.

Measuring the correlation of shocks between the UK and the core of Europe

by S.G. Hall and B. Yhap

A look at the correlation of inflation and GDP shocks between the UK and the three major European EMU countries using the orthogonal GARCH model.

\section{No. 214.}

Economic integration and openness in Europe and East Asia by Ray Barrell and Amanda Choy

A comparison of developments in integration in Europe and East Asia. The process is political as well as economic, and the stimulation of competition more important than the generation of trade in achieving European objectives.

No. 215 .

A firm choice: law firms' preferences in the recruitment of trainee solicitors

\section{by Heather Rolfe and Tracy Anderson}

An examination of the equality of opportunity for prospective entrants into the UK legal profession, which finds different rates of success in gaining a contract according to applicants' background and characteristics, including race and ethnicity, and evidence of bias in the allocation of the more prestigious training contracts in City and large provincial firms.

\footnotetext{
charge on application to:

NIESR Publications Office

2 Dean Trench Street

Smith Square

London SW1P 3HE
}

All National Institute discussion papers are now available on our website www.niesr.ac.uk or free of
No. 216

The determinants of international migration into the UK: a panel based modelling approach

by James Mitchell and Nigel Pain

A detailed econometric model of the economic and demographic determinants of annual migrant inflows into the UK from a number of different locations finds that the change in migration over the decade to $1998-2000$ is primarily due to population growth in the source locations and the continuing pull effects from the rise in the migrant stock and per capita incomes in the UK relative to the source location.

\section{No. 217}

Foreign direct investment in industrial $R \& D D$ and exchange rate uncertainty in the UK

by Bettina Becker and Stephen G. Hall

An investigation into the role of exchange rate uncertainty in determining foreign direct $R \& D$ investment into the UK, estimating an econometric model using a panel of manufacturing industries. Results suggest that an increase in the volatility of the euro-dollar exchange rate tends to relocate R\&D investment from the Euro Area into the UK.

\section{No. 218}

Macroeconomic policy in Europe: experiments with monetary responses and fiscal impulses

by Ray Barrell, Bettina Becker, Joseph Byrne, Sylvia Gottschalk, Ian Hurst and Desirée van Welsum

A discussion of the main model properties of NiGEM, the National Institute's large-scale macroeconometric model.

\section{No. 219}

Is there an ICT impact on TFP? A heterogeneous dynamic panel approach

\section{by Mary O'Mahony and Michela Vecchi}

New evidence is provided on the impact of Information and Communication Technology (ICT) on Total Factor Productivity (TFP), comparing the results from standard panel data techniques with an heterogeneous dynamic panel data estimation method. The alternative technique used, which allows for industry specific dynamics, yields a positive and significant long-run impact of ICT on TFP. 


\section{National Institute Economic Review}

\section{Editor}

M.R. Weale, Director, NIESR

\author{
Editorial Board \\ R.J. Barrell \\ G.S. Clisham \\ D. Holland \\ G. Mason \\ P. Meadows \\ H. Metcalf \\ S.J. Prais \\ R. Riley
}

\section{Council of Management}

Sir Brian Corby (President)

Professor Stephen Nickell (Chairman)

N.C.F. Barber

Professor C. Bean

C. Bowe

Professor W. Buiter

Lord Burns

Professor C. Goodhart

H.H. Liesner

Sir Peter Middleton

Sir Nicholas Monck

Sir Michael Scholar

A. Turner

Dr S. Wadhwani

Professor K. Wallis

M.R. Weale (Director)

In 2003 National Institute Economic Review [ISSN; 0027ñ 901] is published in January, April, July and October by SAGE Publications (London, Thousand Oaks, CA and New Delhi).

Annual subscription: full rate (including electronic version): $£ 199 / \mathrm{US} \$ 318$; individual rate: $£ 96 / \mathrm{US} \$ 154$; secondary school/teacher/student: $£ 26 /$ US $\$ 41$. Single issue rates: full: $£ 51 /$ US $\$ 81$; individual: $£ 25 /$ US $\$ 40$; teacher/ student: $£ 8 /$ US\$11. Apply to the Marketing Department at SAGE Publicationsí London address. Full rate subscriptions include the right for members of the subscribing institution to access the electronic content of the journal (except the Statistical Appendix) at no extra charge from SAGE. The content can be accessed online through a number of electronic journal intermediaries, who may charge for access. Full details are available on our website: http://www.sagepublications.com. Student discounts, single issue rates and advertising details are available from SAGE Publications Ltd, 6 Bonhill Street, London EC2A 4PU, UK. Tel + 44 (0)20 73740645; Fax + 44 (0)20 73748741 [e-mail: subscriptions@sagepub.co.uk; website www.sagepublications.com; and in North America from SAGE Publications Ltd, PO Box 5096, Thousand Oaks, CA 91359, USA.

\section{Aims and Scope}

The Review is the quarterly publication of the National Institute of Economic and Social Research ñ one of Britainis oldest and most prestigious independent research organisations. The Instituteis objective is to promote, through quantitative research, a deeper understanding of the interaction of economic and social forces that affect peopleís lives so that they may be improved. It has no political affiliation, and receives no core funding from government. Its research programme is organised under the headings of Economic Modelling and Analysis; Productivity; Education and Training and the International Economy.

Copyright (C) National Institute of Economic and Social Research, 2003. Apart from fair dealing for the purposes of research or private study, or criticism or review, and only permitted under the Copyright, Designs and Patents Act 1988 , this publication may only be reproduced, stored or transmitted, in any form or by any means, with the prior permission of the Publishers, or in the case of reprographic reproduction, in accordance with the terms or licences issued by the Copyright Licensing Agency. Inquiries concerning reproduction outside those terms should be sent to the publishers at the above mentioned address. Periodicals postage rate is pending at Rahway, NJ. POSTMASTER. Notification of any change of address should be sent to: National Institute Economic Review, clo Mercury Airfreight International Ltd, 365 Blair Road, Avenel, New Jersey 07001, USA.

The Review welcomes the offer of high quality articles describing findings of social or economic research. Articles should normally comprise $4 \tilde{n} 10,000$ words, excluding tables. All articles are externally refereed, but the Review is able to organise quick publication in appropriate cases. Full notes for contributors are available from Fran Robinson (email: f.robinson@niesr.ac.uk). website: http://www.niesr.ac.uk. Articles intended for publication should be sent to National Institute Economic Review, 2 Dean Trench Street, London SW1P 3HE, or as pdf files to Fran Robinson, email: f.robinson@niesr.ac.uk.

The Review is abstracted in Anbar International Management Database, Linguistics and Language Behavior Abstracts, World Banking Abstracts, Worldwide Political Science Abstracts, Sociological Abstracts and Social Services Abstracts. It is indexed in Business Periodicals Index, EconLit, IBZ: International Bibliography of Periodical Literature, e-JEL and JEL on CD.

Printed by Direct Image, London.

ISSN: 0027-9501 